\title{
Cattle Egrets (Bubulcus ibis) Control the Population of House Flies (Musca domestica) in Garbage Dumping Sites: A Comparison between Two Garbage Dumping Sites, Kandy, Sri Lanka
}

\author{
R.L. Jayaratne* , I.C. Perera, D.W. Weerakoon, S.W. Kotagama \\ Department of Zoology, University of Colombo, Sri Lanka \\ *ravindrajayaratne@yahoo.com
}

\begin{abstract}
House flies spread many communicable diseases such as cholera, dysentery and spread parasitic infections. Therefore, it is important to control house flies at garbage dumping sites as they are a rich source of disease agents. Cattle Egret (Bubulcus ibis) is one of the common wetland birds in Sri Lanka, often seen foraging on flies at garbage dumping sites. Referring to the preliminary observations reported before, two garbage dumping sites were selected from Kandy district.
\end{abstract}

Digana garbage dumping site $\left(7.26^{0} \mathrm{~N} 80.74^{\circ} \mathrm{E}\right)$ was selected as a Cattle Egret occupied site and Panvila garbage dumping site $\left(7.22^{\circ} \mathrm{N} 80.43^{\circ} \mathrm{E}\right)$ was selected as the control site where no Cattle Egrets were recorded. The adult house flies (Musca domestica) were counted which random quadrate sampling twice a month for $5 \mathrm{~min}$. Birds were counted from 08:00 to 10:00 hrs by point count method with a binocular. Cattle Egrets, Crows, Common Mynahs, Spotted Doves, Green bee-eaters, House Sparrows, Black Robins, Indian Pond Herons and Asian Palm Swifts were identified as bird species in Digana garbage dumping site and only Common Mynas, Spotted Doves and Asian Palm Swifts were observed in Panvila site. A strong correlation between populations of Cattle Egrets and house flies was observed in the Digana garbage dumping site $(<0.05)$. Since major food item of Cattle Egret is insects, they are attracted to waste dumping site, which provides abundant dipterans maggots at low energy expenditure. However, the house fly population was significantly high in Panvila site than Digana site as Cattle Egrets were not observed in Panvila site. Also In both sites, no correlation was observed between populations of other bird species and population of house flies $(0.05<)$. During breeding season, the Cattle Egrets were observed to be migrating away from the Digana site and were not recorded in late June. No Cattle Egrets in July to September were observed in this site. The number of house flies was clearly increased during this period and with the return of Cattle Egrets after breeding season the numbers of house flies decrease dramatically. The present study shows that there is a strong relationship between population of house flies and Cattle Egret abundance.

Keywords: Cattle Egrets, Garbage dumping sites, House flies 